\title{
HIV/AIDS Patients' Survival Rate between One Co-infection and More Than One Opportunistic Co-infection at Haji Adam Malik General Hospital Medan in 2015-2017
}

\author{
Rizal Abdul Munaf ${ }^{1}$, Tambar Kembaren², Restuti Hidayani S², Putri C Eyanoer \\ ${ }^{1}$ Department of Internal Medicine, Medical Faculty, Universitas Sumatera Utara, H. Adam General Hospital \\ Malik Medan, Indonesia. \\ ${ }^{2}$ Division of Tropical Infection, Department of Internal Medicine, Medical Faculty, Universitas Sumatera Utara, \\ H. Adam General Hospital Malik Medan. \\ ${ }^{3}$ Department of Statistical Science, Medical Faculty, Universitas Sumatera Utara, H. Adam General Hospital \\ Malik Medan, Indonesia.
}

Corresponding Author: Rizal Abdul Munaf

\section{ABSTRACT}

Background: AIDS is a collection of disease symptoms caused by HIV that damages the human immune system. Decreased immunity causes the patient to be very susceptible to various, often fatal, infectious diseases (opportunistic infections).

Aim: To determine the difference in HIV/AIDS patients' survival rate between one co-infection and more than one opportunistic co-infection at Haji Adam Malik Hospital Medan in 20152017.

Methods: This is a retrospective cohort analytic study using secondary data from medical records of HIV patients from January 2015December 2017. The samples were 34 HIV/AIDS patients who met the inclusion and exclusion criteria, selected by consecutive technique sampling. Descriptive statistical analysis was used for demographic data. Kaplan Meier's statistical analysis was used for endurance or survival tests. The difference was considered statistically significant if $\mathrm{p}<0.05$.

Results: The most opportunistic infections found were diarrhea in 265 subjects (55.67\%), followed by toxoplasmosis in 159 subjects (33.40\%), oral candidiasis 141 subjects (29.62\%), CMV 78 subjects (16.39\%), pneumonia 63 subjects (13.24\%), sepsis 62 subjects (13.03\%), PCP 45 subjects $(9.45 \%)$, hepatitis B 38 subjects (7.98\%), chlamydia 24 subjects (5.04\%), hepatitis C 14 subjects (2,
94\%), Herpes zoster 11 subjects (2.31\%), lymphadenopathy 4 subjects $(0.84 \%)$, and the least common were NHL 1 subject $(0.21 \%)$ and Penicilosis 1 subject (0.21\%).

Conclusion: The HIV patients' survival rates are different based on the number of opportunistic infections. According to the order, the most common opportunistic infections were diarrhea, toxoplasmosis, and oral candidiasis.

Keywords: HIV/AIDS, opportunistic infections, oral candidiasis, toxoplasmosis, diarrhea

\section{INTRODUCTION}

Data from the Indonesian Ministry of Health stated that no country is currently free from HIV/AIDS problems. Human Immunodeficiency Virus (HIV) is a virus that attacks the human immune system and causes acquired immunodeficiency syndrome (AIDS). AIDS is a collection of disease symptoms caused by HIV that damages the human immune system. Decreased immunity causes the patient to be very susceptible to various, often fatal, infectious diseases (opportunistic infections). ${ }^{[1]}$

In Indonesia, 640,000 people are living with HIV, 46,000 are newly infected with HIV, and 38,000 are dying from AIDSrelated diseases. AIDS-related deaths have 
increased $60 \%$ since 2010, from 24,000 deaths to 38,000 deaths. However, the number of new HIV infections has decreased, from 63,000 to 46,000 in the same period. It is estimated that the number of HIV/AIDS cases in Indonesia ranks third after India and China. ${ }^{[2]}$ In addition, it is estimated that 543,100 people were living with HIV and AIDS (PLWHA) in 2020. By the end of 2019, it was reported that 377,564 PLWHA knew their HIV-infected status, and 127,613 PLWHA (23.5\% of the total estimated PLWHA in 2020) were on ARV treatment. ${ }^{[1]}$ AIDS incidence in North Sumatra was 12.12 per 100,000 population by the province, which ranks 17th out of 33 provinces throughout Indonesia. ${ }^{[3]}$

The World Health Organization
$(\mathrm{WHO})$ reported that opportunistic infections (OIs) vary in different countries. In the United States, the most commonly found OIs were Kaposi's sarcoma (21\%), followed by oral candidiasis (13\%), cryptococcosis (7\%), cryptosporidiosisisosporiasis (6.2\%), cytomegalovirus (5\%), toxoplasmosis (3\%), and Pulmonary Tuberculosis (3\%). ${ }^{[4]}$ Data from the Ministry of Health Republic Indonesia showed that the proportion of OI in AIDS patients in Indonesia consisted of oral candidiasis (80.8\%), tuberculosis (40.1\%), cytomegalovirus (28.8\%), Toxoplasma encephalitis (17.3\%), PCP (13.4\%), Herpes Simplex (9.6\%), Mycobacterium Avium Complex (4.0\%), Cryptosporodiosis (2.0\%), and Pulmonary Histoplasmosis (2.0\%). Most AIDS patients had Tuberculosis (67.4\%), Toxoplasmosis (22.8\%), Candidiasis (5.4\%), Chronic Diarrhea (3.3\%), and Hepatitis C (1.1\%). However, there has been no research that states the survival rate of HIV/AIDS patients is associated with the number of opportunistic infections. ${ }^{[5]}$

\section{MATERIAL AND METHOD}

This study is a retrospective cohort analytic study using secondary data taken from HIV patients' medical records from January 2015-December 2017. The study was conducted at Haji Adam Malik General Hospital Medan with approval by USU Medical Faculty Research Ethics Commission, conducted in October November 2020.

Samples were 34 HIV/AIDS inpatients of Haji Adam Malik Hospital Medan and diagnosed in 2015 who met the inclusion criteria, namely patients who had been diagnosed with HIV positive non-TB and aged $>18$ years. The exclusion criteria were incomplete patient data, patients who did not comply with ARV drugs schedule and opportunistic infection drugs, patients who moved health facilities, lost-to-followup patients, and patients who did not have opportunistic infections. The sampling technique in this study was non-probability sampling, namely the consecutive sampling technique.

\section{Statistical Methods}

Descriptive statistical analysis was used for demographic data. Kaplan Meier's statistical analysis was used for endurance or survival tests. The difference was considered statistically significant if $\mathrm{p}<0.05$.

\section{RESULT}

The mean survival of HIV patients with one infection was 1089.05 , meaning that $50 \%$ of HIV patients with one infection died within 2.90 years. The mean survival of HIV patients with 2-3 infections was 502.39, meaning that $50 \%$ of HIV patients with 2-3 infections died within 1.37 years. Meanwhile, the mean survival of HIV patients with 4 infections was 132.83, meaning that $50 \%$ of HIV patients with $\geq 4$ infections died within 0.36 years. Overall mean survival was 2.03 years.

Table 1 Characteristics of research subjects based on number of opportunistic infections

\begin{tabular}{|l|l|l|}
\hline $\begin{array}{l}\text { Number of Opportunistic } \\
\text { Infections }\end{array}$ & $\mathbf{n}$ & $\begin{array}{l}\text { Mean survival } \\
\text { (days) }\end{array}$ \\
\hline 1 & 207 & 1089.059 \\
\hline $2-3$ & 157 & 502.399 \\
\hline$\geq 4$ & 36 & 132.833 \\
\hline Overall & & 741.341 \\
\hline
\end{tabular}




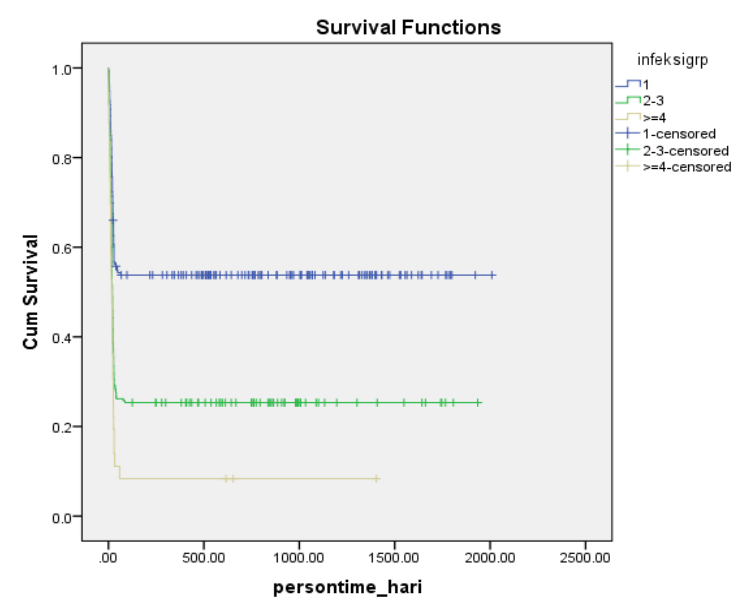

Figure 1. Characteristics of research subjects based on number of opportunistic infections

\section{Characteristics of Research Subjects Based on Gender}

A total of 476 research subjects who had met the inclusion and exclusion criteria were included in the study. The majority of the research subjects were men, as many as 337 subjects (70.8\%\%), while women were 139 subjects (29.2\%).

Table 2. Characteristics of research subjects by gender

\begin{tabular}{|l|l|}
\hline Gender & n (\%) \\
\hline Male & $337(70,80 \%)$ \\
\hline Female & $139(29,20 \%)$ \\
\hline
\end{tabular}

\section{Characteristics of Research Subjects Based on Age}

The majority of $236 \quad(49.6 \%)$ subjects were 25-34 years old, followed by $35-44$ years with 136 subjects (28.6\%), 4554 years old with 54 subjects (11.3\%), 1824 years old with 29 subjects $(6.1 \%)$, and the least was $>54$ years old with 21 subjects $(4.4 \%)$.

Tabel 3. Characteristics of research subjects by age group

\begin{tabular}{|l|l|}
\hline Age (years old) & n (\%) \\
\hline $18-24$ & $29(6.1)$ \\
\hline $25-34$ & $236(49.6)$ \\
\hline $35-44$ & $136(28.6)$ \\
\hline $45-54$ & $54(11.3)$ \\
\hline$>54$ & $21(4.4)$ \\
\hline Total & $476(100)$ \\
\hline
\end{tabular}

\section{Characteristics of Research Subjects Based on CD4 Levels}

The number of CD4 T lymphocytes was obtained from the medical records. The average CD4 T lymphocyte level was 12.12 cells/L; most subjects had CD4 levels <50 cells/ $\mu \mathrm{L}$, namely 471 subjects (98.95\%), while CD4 levels $\geq 50$ cells $/ \mu \mathrm{L}$ were found in 5 patients $(1.05 \%)$.

Table 4. Characteristics of Research Subjects Based on CD4 Levels

\begin{tabular}{|l|l|}
\hline Kadar CD4 & n (\%) \\
\hline$<50$ & $471(98.95)$ \\
\hline$\geq 50$ & $5(1.05)$ \\
\hline Total & $476(100)$ \\
\hline
\end{tabular}

Characteristics of Research Subjects by the Type of Opportunistic Infection

The most opportunistic infections found were diarrhea in 265 subjects (55.67\%), followed by toxoplasmosis in 159 subjects $(33.40 \%)$, oral candidiasis 141 subjects (29.62\%), CMV 78 subjects (16.39\%), pneumonia 63 subjects (13.24\%), sepsis 62 subjects (13.03\%), PCP 45 subjects (9.45\%), hepatitis B 38 subjects (7.98\%), chlamydia 24 subjects (5.04\%), hepatitis C 14 subjects (2, 94\%), Herpes zoster $11 \quad$ subjecst $(2.31 \%)$, lymphadenopathy 4 subjects $(0.84 \%)$; while the least common were NHL 1 subject (0.21\%) and Penicilosis 1 subject (0.21\%).

Table 5. Characteristics of Research Subjects by the Type of Opportunistic Infection

\begin{tabular}{|l|l|}
\hline Opportunistic Infection & n (\%) \\
\hline Diarrhea & $265(55.67)$ \\
\hline Toxoplasmosis & $159(33.40)$ \\
\hline Oral Candidiasis & $141(29.62)$ \\
\hline CMV & $78(16.39)$ \\
\hline Pneumonia & $63(13.24)$ \\
\hline Sepsis & $62(13.03)$ \\
\hline PCP & $45(9.45)$ \\
\hline Hepatitis B & $38(7.98)$ \\
\hline Chlamydia & $24(5.04)$ \\
\hline Hepatitis C & $14(2.94)$ \\
\hline Herpes Zooster & $11(2.31)$ \\
\hline Lymphadenopathy & $4(0.84)$ \\
\hline NHL & $1(0.21)$ \\
\hline Penicilosis & $1(0.21)$ \\
\hline
\end{tabular}

\section{DISCUSSION}

The survival rate of HIV patients according to the number of opportunistic infections

According to data from the Ministry of Health in 2019, the lower CD4 level in HIV/AIDS patients resulted in lower life expectancy. The authors do not have previous research data on survival rates similar to this study; however, some literature stated that the lower the CD4 cell count in HIV patients, the more opportunistic infections they would have. In 
addition, a low CD4 count can also indicate a patient's high viral load. ${ }^{[1]}$

The Kembaren study in Adam Malik Hospital Medan stated that the survival rate of HIV/AIDS patients was 59\%; however, this study was slightly different since the survival rate was associated with patients' CD4 levels. The Kembaren study in 2010 also stated that patients with CD4100 had better survival rates compared to patients with CD4<100 (83\% vs. 56\%). ${ }^{[6]}$

Yogani's study stated that there was no relationship between the number of opportunistic infections and the patient's survival rate; however, the study subjects were from outpatients only, and most of the study subjects had less than 2 opportunistic infections, which was around $85.2 \%{ }^{[7]}$

Ladyani's research in Bandar Lampung did not state the survival rate of HIV/AIDS patients, but Ladyani's research stated that there was a relationship between patient's CD4 levels and the number of opportunistic infections that the patient had. In this study, the average CD4 level of patients with opportunistic infections was 187 cells/L, toxoplasmosis was 156.5 cells/L, and candidiasis was 226.00 cells/L. ${ }^{[8]}$

\section{Characteristics of Research Subjects by the Type of Opportunistic Infection}

According to Vinod in Kozhikode, India, the most opportunistic infections were oral candidiasis as much as $52 \%$, followed by PCP 15\%. This is similar to Youn's 2016 study, which stated that oral candidiasis was the most common opportunistic infection. However, in this study, the most opportunistic infections were diarrhea 265 subjects (55.67\%), followed by toxoplasma 159 subjects (33.40\%), and oral candidiasis 141 subjects (29.62\%). This may be due to differences in the research area. ${ }^{[9]}$

Rubaihayo's research in Uganda in 2017 stated that overall, the most opportunistic infections were worms with $30 \%$, followed by diarrhea with $25.5 \%$. Meanwhile, oral candidiasis was $19.4 \%$. Worms are the most common opportunistic infection because most HIV/AIDS patients in Uganda are of low socioeconomic status with very poor hygiene. This is also related to diarrhea, which was ranked second in this study. ${ }^{[10]}$

Meanwhile, the 2019 study by Ladyani in Bandar Lampung stated that diarrhea was the most opportunistic infection (47.8\%). According to researchers, diarrhea is the most common opportunistic infection due to abnormal stomach acid production in HIV patients, resulting in a decreased normal flora that neutralizes microorganisms that cause diarrhea. In addition, diarrhea can also occur due to gastrointestinal infections, intestinal motility disorders, immunity, and intestinal microflora environment imbalance. The decrease in the immune system is closely related to decreased CD4 levels in HIV/AIDS patients, causing susceptibility to infection, which was also in accordance with this study. ${ }^{[8]}$

The 2014 study by Widiyanti in Papua showed different results from our study. Widiyanti et al. stated that pulmonary TB was the most common opportunistic infection in Papua, particularly at Jayapura Dok II Hospital. However, the study only had 67 samples, and only 21 subjects had opportunistic infections ( $\mathrm{p}=0.02) .{ }^{[12]}$

\section{Characteristics of research subjects by gender and age group}

In 2018, according to UNAIDS, the number of HIV/AIDS patients was estimated at 37.9 million people, and most patients were within productive age. Of these, approximately $48.1 \%$ were male, and $51.9 \%$ were female. ${ }^{[2]}$

The incidence of HIV/AIDS is more prevalent in men because they are more involved in actively transmitting the virus through sexual intercourse with multiple partners, more exposed to injected-drug use, and same-sex sexual activity. The risk of transmission after a single encounter with an HIV source is estimated to be 1 in 150 with sharing needles, 1 in 300 with percutaneous exposure at work, 1 in 300-1000 with 
receptive anal intercourse, 1 in 500-1250 with receptive vaginal intercourse, 1 in 1000-3000 with insertive sexual intercourse, and 1 in 3000 with anal intercourse. ${ }^{[1]}$

A 2017 study in Uganda by Rubaihayo also stated that more male patients suffer from HIV/AIDS than women. A 2016 study by Kate also stated that more men suffer from HIV AIDS, with 49,483 patients (78\%) being male. A study by Vania in 2017 also stated that men were the most HIV/AIDS patients. There does not seem to be any differences in the characteristics of previous studies, which stated that men are the most patients with HIV/AIDS. ${ }^{[10,11]}$

The median age of the subjects in this study was 35.6 years old. Most subjects (49.6\%) were 25-34 years old. Furthermore, most subjects were in productive age, which would greatly influence society's economy and social function. Therefore, HIV/AIDS case is a matter that must be of grave concern due to its broad impact on the economy and quality of life.

This result is in accordance with the report on HIV/AIDS development in the first quarter of 2019. The highest percentage of infections in the 25-49 years old group was $70.8 \%$, followed by $15.1 \%$ in the $20-24$ years old group and $8.9 \%$ in the $>50$ years old group. AIDS was found to be highest in the 30-39 years old group (35\%), followed by the 20-29 years old group (24.5\%) and 40-49 years old (22.7\%). ${ }^{[13]}$

According to data from the Ministry of Health in 2017, the cumulative number of AIDS cases up to December 2016 was 86,780 cases; the highest age group was 2029 years old (31.4\%), followed by 30-39 years old group (30.6\%), 40-49 years old (12.8\%), 50-59 years old (4.5\%) and 15-19 years old group (2.7\%). ${ }^{[1]}$ According to the study by Kate and Vania, the 35-44 years old age group was the group with the highest number of HIV/AIDS patients. The study by Natalia in 2015 also mentioned similar findings. ${ }^{[11]}$ Productive age was stated as the cause of such a high spread of HIV in the productive age.

\section{Characteristics of Research Subjects Based on CD4 Levels}

CD4+ $\mathrm{T}$ lymphocytes play an important role in regulating immune response against pathogens by carrying out various functions, including activating cells in the innate immune system (B lymphocytes, cytotoxic $\mathrm{T}$ cells, and nonimmune cells). CD4+ $\mathrm{T}$ lymphocytes also play a role in suppressing immune reactions. The low number of CD4+ T lymphocytes will reduce the immune system against pathogens so that patients become susceptible to IO. ${ }^{[14]}$

CD4 is part of white blood cells or lymphocytes and an important part of the human immune system, also called the T-4 cells, or helper cells (T-Helper). When humans are infected with HIV, the most often infected cells are CD4 cells. When CD4 cells multiply to fight off any infection, they also make more copies of HIV. The decrease in CD4 cells indicates that the immune system is getting damaged. In addition, the lower number of CD4 cells in the human body would result in more susceptibility to sickness or opportunistic infections. ${ }^{[14]}$

The mean CD4 $\mathrm{T}$ lymphocyte level in this study was 12.12 cells/uL; most subjects had CD4 levels of $<50$ cells $/ \mu \mathrm{L}$, namely 471 subjects $(98.95 \%)$, while the $\geq 50$ cells/L CD4 levels were found in 5 subjects (1.05\%). This result was due to the examination of the CD4 level being conducted when the patients were admitted. CD4 count is very influential on the number of opportunistic infections. Hospitalized patients generally have lower CD4 cell counts.

Bossart 2020 in Switzerland obtained a characteristic CD4 level in patients with PCP opportunistic infections was 39 cells/uL, almost the same as the results of this study. However, the study by Bossart only focused on PCP opportunistic infections. ${ }^{[15]}$ The study by Ladyani in 2019 in Bandar Lampung stated that most patients' CD4 levels were below 200 cells/uL (58.2\%). ${ }^{[8]}$ 
Rizal Abdul Munaf et.al. HIV/AIDS patients' survival rate between one co-infection and more than one opportunistic co-infection at Haji Adam Malik General Hospital Medan in 2015-2017.

There were differences in the survival rates of HIV patients based on the number of opportunistic infections. For the distribution of HIV/AIDS patients' survival rate between one and more than one opportunistic infection, we found 1 patient with one infection died within 2.90 years, patients with 2-3 infections died within 1.37 years, and patients with $\geq 4$ infections died within 0.36 years. The overall survival rate was 2.03 years. In addition, the most common opportunistic infections, according to the order, were diarrhea, toxoplasmosis, and oral candidiasis.

\section{CONCLUSION}

For the distribution of HIV/AIDS patients' survival rate between one and more than one opportunistic infection, we found 1 patient with one infection died within 2.90 years, patients with 2-3 infections died within 1.37 years, and patients with $\geq 4$ infections died within 0.36 years. The overall survival rate was 2.03 years. There were differences in the survival rates of HIV patients based on the number of opportunistic infections. The most common opportunistic infections, according to the order, were diarrhea, toxoplasmosis, and oral candidiasis.

\section{ACKNOWLEDGEMENT}

This research was supported by the Faculty of Medicine Universitas Sumatera Utara. The authors thank colleagues from the Division of Tropical Infections, Department of Internal Medicine, and Department of Statistical Science, for providing insight, assistance and expertise that had greatly helped authors throughout this research.

\section{Conflict of Interest: None}

Source of Funding: None

Ethical Approval: Approved

\section{REFERENCES}

1. Kementrian Kesehatan RI. Pedoman Nasional Pelayanan Kedokteran Tata Laksana HIV.: Pusat Data dan Informasi Kesehatan RI. 2019

2. UNAIDS. Global Report.UNAIDS Report on the Global AIDS Epidemic 2019. 2019 (online).Available at http://www.unaids.org

3. Komisi Penanggulangan AIDS Provinsi Sumatera Utara. Laporan HIV dan AIDS 2015. Komisi Penanggulangan AIDS Provinsi Sumatera Utara. 2016. Medan

4. World Health Organization. HIV related opportunistic diseases. 2010. Diunduh dari: URL:

http://www.who.int/hiv/pub/amds/opportu_e n.pdf

5. Direktorat Jenderal Pencegahan dan Pengendalian Penyakit, Kemenkes RI, Surat laporan perkembangan HIV-AIDS \& Infeksi Menular Seksual (IMS) Triwulan IV Tahun 2018

6. Kembaren $\mathrm{T}$ dan Ginting $\mathrm{J}$, Ketahanan hidup 2 tahun pasien HIV/AIDS yang mendapat obat ARV Di RS H. Adam Malik Medan.2010. Presented at Perhimpunan Dokter Infeksi Tropik Indonesia Bali tahun 2012

7. Yogani, I., Karyadi, T.H., Uyainah, A. and Koesnoe, S., Faktor-faktor yang berhubungan dengan kenaikan CD4 pada pasien HIV yang mendapat highly active antiretroviral therapy dalam 6 bulan pertama. Jurnal penyakit dalam Indonesia. 2015. 2(4), pp.217-222

8. Ladyani, F. and Kristianingsih, A., Hubungan antara jumlah CD4 pada pasien yang terinfeksi HIV/AIDS dengan infeksi oportunistik di Rumah Sakit Umum Abdul Moeloek Bandar Lampung tahun 2016. Jurnal Kedokteran Universitas Lampung. 2019. 3(1), pp.34-41

9. Vinod, P.K., Radhakrishnan, C. and Pk, S., Incidence and spectrum of opportunistic infections among HIV infected patients attending government medical college, Kozhikode. The Journal of the Association of Physicians of India. 2018. 66(7), pp.3336

10. Rubaihayo, J., Tumwesigye, N.M., KondeLule, J., Wamani, H., Nakku-Joloba, E. and Makumbi, F., 2016. Frequency and distribution patterns of opportunistic infections associated with HIV/AIDS in 
Rizal Abdul Munaf et.al. HIV/AIDS patients' survival rate between one co-infection and more than one opportunistic co-infection at Haji Adam Malik General Hospital Medan in 2015-2017.

Uganda. BMC research notes. 2016. 9(1), pp.1-16.

11. Katz, J., Kaposi Sarcoma: Practice Essentials, Background, Pathophysiology. [online] Emedicine.medscape.com.2020. Available at: $<$ https://emedicine.medscape.com/article/27 9734-overview $>$ [Accessed 27 January 2020].

12. Widiyanti, M. and Hutapea, H. Hubungan jumlah Cluster of Differentiation 4 (CD4) dengan Infeksi Oportunistik pada pasien HIV/AIDS di Rumah Sakit Umum Daerah (RSUD) DOK II Jayapura. Jurnal Biologi Papua. 2015. 7(1), pp.16-21

13. Direktorat Jenderal Pencegahan dan Pengendalian Penyakit, Kemenkes RI, Surat laporan perkembangan HIV-AIDS \& Infeksi Menular Seksual (IMS) Triwulan I Tahun 2019
14. Luckheeram, R.V., Zhou, R., Verma, A.D. and Xia, B. CD4+ T cells: differentiation and functions. Clinical and developmental immunology, 2012

15. Bossart, S., Mühlethaler, K., Garzoni, C. and Furrer, H., Is real time PCR preferable to the direct immunofluorescence in the diagnosis of pneumocystis jirovecii pneumonia in HIV-infected patients?. BMC research note. 2020. 13, pp.1-5

How to cite this article: Rizal Abdul Munaf, Tambar Kembaren, Restuti Hidayani S et.al. HIV/AIDS patients' survival rate between one co-infection and more than one opportunistic co-infection at Haji Adam Malik General Hospital Medan in 2015-2017. International Journal of Research and Review. 2021; 8(12): 447-453. DOI: https://doi.org/10.52403/ijrr. 20211255 